\title{
La educación escolar en el norte de Yakutia (Rusia) en el contexto de un enfoque indígena
}

\section{School education in the north of Yakutia (Russia) in the contexto of an indigeno}

\author{
Nikolai Dmitrievich Neustroev, ${ }^{1}$ Anna Nikolaevna Neustroeva, ${ }^{2}$ Tuyaara Alekseevna Shergina, ${ }^{3 a}$ \\ Alina Alekseevna Kozhurova ${ }^{4}$, y Sardaana Ignatievna Osipova ${ }^{5}$ \\ M.K. Ammosov North-Eastern Federal University, Yakutsk, Russia ${ }^{12345}$ \\ ORCID: https://orcid.org/0000-0002-7646-2362 1 \\ ORCID: https://orcid.org/0000-0003-3824-6578 \\ ORCID: https://orcid.org/0000-0001-5414-5617 \\ ORCID: https://orcid.org/0000-0001-7036-3462 \\ ORCID: https://orcid.org/0000-0002-2433-6436
}

Recibido: 15 de julio de 2020

Aceptado: 15 de octubre de 2020

\begin{abstract}
The relevance of this research is determined by the modernization and regionalization of the education system in the context of the requirements of new Federal State Educational Standards (FSES), and taking into account the specifics of school education in the North of the Republic of Sakha (Yakutia) based on an indigenous approach. The purpose of the study is the variable organization of school education in the North, taking into account the specific traditional way of living and activity of the indigenous peoples of the North. Guiding research approaches are sociocultural, ethnopedagogical, and active in in terms of the local applied character of the study. The authors of present study reveal the features and problems of school education organization, and the ways of its variable implementation according to the requirements of FSES in the specific conditions of the North.Research methods. The guiding method of the study is a pedagogical experiment, an analysis of school education in the North in the context of an indigenous approach, and the implementation of the program "We Are Children of the Land of Olonkho". The authors prove the necessity to expand social functions of rural schools in the North in terms of socio-pedagogical centers development in the places of compact residence of indigenous peoples.
\end{abstract}

Keywords: Yakutia; Republic of Sahka; School education; Regionalization; Ethnocultural; Ethnopedagogization; Indigenous peoples of Russia. 


\section{Resumen}

La relevancia de esta investigación está determinada por la modernización y regionalización del sistema educativo en el contexto de los requisitos de los nuevos Estándares Educativos del Estado Federal (FSES), y teniendo en cuenta las particularidades de la educación escolar en el norte de la República de Sakha (Yakutia) basado en un enfoque indígena. El propósito del estudio es la organización variable de la educación escolar en el Norte, teniendo en cuenta la forma de vida y actividad tradicional específica de los pueblos indígenas del Norte. Los enfoques rectores de la investigación son socioculturales, etnopedagógicos y activos en términos del carácter local aplicado del estudio. Los autores del presente estudio revelan las características y problemas de la organización de la educación escolar, y las formas de su implementación variable de acuerdo a los requerimientos del FSES en las condiciones específicas del Norte. Métodos de búsqueda. El método rector del estudio es un experimento pedagógico, un análisis de la educación escolar en el norte en el contexto de un enfoque indígena y la implementación del programa "Somos niños de la tierra de Olonkho". Los autores evidencian la necesidad de ampliar las funciones sociales de las escuelas rurales del Norte en términos de desarrollo de centros sociopedagógicos en los lugares de residencia compacta de los pueblos indígenas.

Palabras clave: Yakutia; República de Sakha; Educación escolar; Regionalización; Etnocultural; Etnopedagogización; Pueblos indígenas de Rusia.

\section{Introduction}

Modernization of education in the North of Yakutia, as a process of refocusing of its development in accordance with modern societal, involves the solution of schools' highpriority socio-economic and ethnocultural problems in compact settlements of indigenous peoples of the North, i.e., preparing future employees and social adaptation of children to real life. In this context, the national and regional aspects of education are considered as an integral part of the Arctic circumpolar civilization (Nikolaeva, Marfusalova, Bugaeva, \& Shadrina, 2020). A school-teacher or educator is not only a carrier of national culture, but also a mediator of different cultures (Baisheva et al., 2017).

Therefore, the purpose of the study is to justify the variable organization of school education in the North, taking into account the specific traditional living of indigenous peoples and active industrial development of the Arctic territories, as a factor of their socioeconomic and ethnocultural development according to current requirements (taking into consideration the previous studies - Neustroev et al., 2017, 2018a, 2018b, 2019). The authors of the research introduce the hypothesis that the implementation of the variable organization of school education in the North provides high-quality education and personality formation for indigenous children, as native culture and language bearers, patriots, housekeepers and workers, and Russian citizens in the framework of FSES ideas implementation. It is meant to solve the following tasks: 
- To reveal the features and problems of the organization of school education in the North;

- To show the variety of forms and methods of teaching, taking into account ethnic and psychophysiological characteristics of children's development, as well as the specific conditions of the Northern schools;

- To prove the necessity of socio-pedagogical centers in the arears of compact residence of indigenous peoples in order to solve socio-economic and ethnocultural problems of the local ethnic community.

\section{Literature review}

The scientific foundations for ethnopedagogical aspects of educational systems were formed in the late 1960s. It was based on national liberation movements of colonial countries and the processes of the formation of the American nation and the Soviet people in terms of the ethnocultural diversity of the population of these countries (Pankin, 2009; Baklanova, 2015). In the United States, indigenous peoples had the possibility for self-determination in accordance with the Indian Education Act (1972), which established a comprehensive approach to meet the unique needs of the American Indians and Alaska Natives (Vinokurova, 2017). A review and evaluation of culturally-oriented educational programs for American Indians in the USA, conducted by David Beaulieu, revealed a socially meaningful character of learning, regarded as a sociolinguistic and semiotic network of stories and relationships (Beaulieu, 2006). Soenke Biermann from Australia notes that many students, especially vulnerable groups, have a growing rejection of, apathy toward, and exclusion from the education system. Indigenous children are not the only ones struggling with the monoculture education system. Therefore, the researcher suggests revising the existing models of teaching and learning, as well as rethinking of the alternative pedagogy and the underlying epistemology (Biermann, 2008).

Margaret Kovach, a Canadian scientist and representative of the First Nations of Canada, developed a transgressive pedagogy, believing that education should serve as a way to create mutually beneficial relations, with all respect and understanding of the peoples' coexistence (Kovach, 2010). Smith points out that these approaches will allow determination of specifics, needs, relevance and significant issues for the indigenous population to assist with self-determination and fostering an understanding of their place in the world. In addition, it will also help to overcome the restrictions of Western generally-accepted epistemology, 
which serves the interests of European scientific thinking and differs from the traditional indigenous worldview and life attitude (Smith, 2005).

More generally, indigenousness implies recognition of the special significance of the relationship between a small group and locality (Merlan, 2009). The number criterion ("small", "indigenous") is a tool for quantitative measurement of peoples or communities, although it can be associated with their spatial and cultural remoteness, as well as with social marginality (Strathern, 2004). Moreover, each indication of the number of indigenous peoples in particular places, which are recognized in the social discourse as the territories of their traditional habitat, contributes to "strengthening the symbolic power of the borders that these minorities create and reproduce" (Trouillot, 2003). In recent years, indigenous peoples have become a powerful political force, and the category of "indigenous peoples" has become one of the most popular in the social sciences (Chilisa, 2012; Harvey, 2002; Moreton-Robinson, 2009; Ismail, Gopalasamy, Saputra, \& Puteh, 2019). The authors of the present research find out how the concept of indigenousness is considered in the works of Russian authors and in terms of what sciences it is studied.

It is worth highlighting the exportation of the issue under study. Early researchers such as Abakumov, Bazanov, Kazan, Krongauz, Tan-Bogoraz et al. revealed the peculiarities of the formation and development of schools in the Far North. The studies of Arsenov, Verin, Sevilgaev, Sturov et al. are devoted to the organization of schools in the national regions of the Russian North-East during the Soviet period. The research works of Afanasyev, Danilov, Neustroev, Portnyagin, Grigoriev, Semenova, Vinokurova, Zhirkova, Popova, Robbek, and Nikitina are popular in the Republic of Sakha (Yakutia). These authors focused on the ethnopedagogy of the peoples of the North, Siberia and the Far East; the rationalization and ethnopedagogization of the educational process in the national schools of Siberia and the North; the specifics of rural ungraded and nomadic schools in the North and the Arctic; and the peculiarities of the education and upbringing of indigenous children of the North according to the specific traditional way of living.

\section{Theoretical background}

Currently, a conceptual position is being developed that in school education in the North, national and regional features of indigenous children's teaching and education are considered as an integral part of the Arctic circumpolar civilization (Vinokurova, Yakovets, 2016). From this perspective, the authors of the present study regard an indigenous approach as the methodological basis for studying the problems of school education in the North 
(Marfusalova, 2020). The inside of the indigenous approach is based on the original knowledge of indigenous researchers and on the mentality and ethnocultural identity of the peoples.

It is declared that the indigenous approach to research is characterized by the analysis of cultural bearers of the stories, tales, and narrations, which form the basis for the search for truth (Nikolaeva, 2013). In this regard, the studies of the Sakha people, as unique examples of indigenous cultures, are characterized by the mentality inherited by generations, way of living, thinking, philosophical worldview, worship to the Nature forces, the originality of the language and culture, and the place of original residence of the ancestors. Thus, despite ethnonational differences, the peoples living in the northern circumpolar territories have similar philosophical worldview, mentality of a northern ethnos, beliefs, and traditions. In particular, the indigenous people of Alaska, Canada, American Indians and others have common pagan beliefs and worship to the forces of Nature and Heaven (Vinokurova, 2016, 2017).

\section{Methods and Materials}

Learning the ethnocultural personality should be based on the material of how people preserve their ethnic cultures in the modern world (Pankin, 2006). This study uses the information about small and nomadic schools of the North of the Republic of Sakha (Yakutia). The authors applied the following methods: the analysis of the Northern schools from contemporary theoretical and pedagogical positions and generalization of practical experience basing on innovative educational ideas; the development of the variable means of educational organizations formation in the north of the Arctic. The comparative historical method made it possible to identify the specific features of small and nomadic schools in the North, namely, their remoteness from the centers, independence, low class filling, and small number of students, different age groups, severe frosts, and lack of teachers of some subjects. According to the conducted experimental work, the authors introduced the program "We Are Children of the Land of Olonkho."

In addition, effective ways and pedagogical support for the formation of value attitude of younger students to ethnic traditions in a multicultural environment were developed. The research materials are analyzed by means of joint experimental work with the teaching staff of 12 typical rural Northern schools on a contractual basis for the laboratory of the problems of rural ungraded schools of the Department of Primary Education of the Pedagogical Institute of NEFU. 
The indigenous approach is essentially an ecological culture-creative pedagogy. It forms a model of a four-dimensional person, in contrast to a three-dimensional technogenic, in contrast to the "personality-family-society" system, in indigenous pedagogy there is one more link "personality-family-nature-society". The intrinsic value of nature is recognized as a pedagogical factor that organizes the necessary interdependence and coexistence on the planet. The greening of education is becoming a demanded factor in the new conditions, named as the coming era of a pandemic. The turn to the strengthening of natural factors implies an appeal to the ecological component of indigenous pedagogy. Indigeneity contains an ethnic cultural-creative factor that ensures the continuity of the spiritual values of the ethnos, in the ethno-ecological environment of which the younger generation is born and brought up (Sergeeva, Shevchenko, Klimenko, Shcherbakova, \& Tikhonovskova, 2018). In modern indigenous pedagogy, introduced into educational organizations of different levels, the graduate model is a personality rooted in native cultures, ready to serve the native people and open to the world community.

\section{Results}

According to the observation and analysis of small and nomadic schools, it was suggested that the proper solution for the problem of the value attitude to ethnic traditions in a multicultural environment would be ensured through the additional experimental program "We Are Children of the Land of Olonkho" (Program), which is based on an indigenous approach. The program is based on the following pedagogical approaches:

- Cultural and indigenous approach, as an objective connection between human and culture, transmission of traditional national culture and the development of universal cultural values;

- Implementation of a multicultural approach in the formation of a value attitude to ethnic traditions in a multinational environment;

- Integrative approach, the use of integration technologies, first of all, the value attitude to ethnic traditions through the educational process;

- The development of the integrity, consistency and depth of the educational process, as the implementation of the program in the learning process involves a multi-level research and analytical approach.

For the other hand, the implementation of the Program has the following purposes: 
Pedagogical. This means to provide methodological support and develop conditions for the formation of the value attitude of younger students to ethnic traditions;

Educational. This means to develop the norms of value attitude as the basis of multicultural communication;

Psychological. This means to develop an emotional culture of interpersonal communication in a multicultural environment, i.e., respect, solidarity, and tolerance towards other people. Since we had to solve this problem through pedagogical means, the leading methodological and didactic principle in elementary school was the ethnoculturality of the educational process. This principle was the basis for the selection of the learning content.

The Program is a system of complementary values, which shows that through the mother language, the individual is aware of and reflects his or her sociocultural origin in the mind in the form of value orientations. They serve for regulation of the perception and attitude to the surrounding reality, starting with the "small motherland", i.e., paternal and grandfather's home area (the place of birth and residence of close relatives), and ending with the global problem of the ethnic group survival and the generic communal environment of its habitat, as well as the concept of ethnic community and self-concept. The authors of the research identify the following direction of value orientations:

- Personal level ("I am a human”, "I am a person", "I am a child of nature”, "I am a son of my people", i.e., a representative of a particular nationality, family and community);

- Socio-ethnic level ("We are the Yakuts", "We are Northerners");

- Institutional level ("We are the family", "We are the hunters", "We are the teachers"), etc.;

- Cultural level (national culture, traditions and customs, as well as other national cultures with a long history). Family and life culture has the strongest impact on the consciousness of young generation. National everyday traditions and customs ensure the continuation of spiritual life of the people, help to overcome difficulties, give additional strength for survival, preserving oneself as a representative of one or another ethnic group.

It is worth highlighting that the orientation to the values of the small motherland (with the transition to the values of Motherland), ethnos, and national culture open up a wide opportunity for teachers to develop a model of the educational system in school. The ultimate goal of education is a self-developing personality as a value with its own social self. The main 
indicators of success of educational work is the child's personal creative development (the dynamics of educability, proficiency, and creativity), the emotional sphere (low level of anxiety and aggressiveness, optimism, and comfort), active involvement in various types of socially significant activities, positive value orientations and humanistic interpersonal relationships in a multicultural environment. Thus, such personality traits as patriotism, civic consciousness, responsibility, humanism, compassion, the search for new things, uniqueness and universality, as well as their formation and upbringing are determined by ethnic and sociocultural values.

The combination of features and problems of the region determine the national regional component as a set of norms and requirements for the structure and the graduates' mandatory minimum content and level of training, having nationally significant traditions of the people living in the region. According to the scientific research on an integrative approach to multicultural educational patterns, the authors introduce the program "We Are Children of the Land of Olonkho", which is Based on an indigenous approach (Table 1; Kozhurova, 2015). 


\section{Table 1}

Experimental program "We are the Children of the Land of Olonkho" for the pupils in grades 1 through 4

\begin{tabular}{|c|c|c|c|}
\hline No. & Sections & Modules & Type of Work \\
\hline I & $\begin{array}{l}\text { "Motherland" } \\
\text { involves the } \\
\text { education of } \\
\text { patriotism, civic } \\
\text { position, tolerance } \\
\text { in behavior and } \\
\text { communication }\end{array}$ & $\begin{array}{l}\text { Module 1. Introduction. My Motherland is } \\
\text { Yakutia. My city, my village. } \\
\text { Module 2. The Great Sons' tale about } \\
\text { Motherland. My Yakutia is the world of } \\
\text { Olonkho. } \\
\text { Module 3. Russia. My Yakutia is part of } \\
\text { Russia. Symbols of my country. } \\
\text { Module 4. Yakutia is the arena of peoples' } \\
\text { friendship. }\end{array}$ & $\begin{array}{l}\text { Lesson, } \\
\text { homework, } \\
\text { conversations, } \\
\text { meetings, } \\
\text { excursions. }\end{array}$ \\
\hline II & $\begin{array}{l}\text { "Family" as the } \\
\text { basis of the entire } \\
\text { parental home. }\end{array}$ & $\begin{array}{l}\text { Module 5. My family. Family tradition and } \\
\text { culture. }\end{array}$ & $\begin{array}{l}\text { Lesson, } \\
\text { homework, } \\
\text { conversation, } \\
\text { training. }\end{array}$ \\
\hline III & “Language”. & Module 6. Native language. & $\begin{array}{l}\text { Homework, quiz, } \\
\text { game. }\end{array}$ \\
\hline IV & “Culture”. & $\begin{array}{l}\text { Module 7. Culture of the Yakut people. } \\
\text { Module 8. Culture of indigenous peoples of } \\
\text { Yakutia. }\end{array}$ & $\begin{array}{l}\text { Integrated } \\
\text { lessons, } \\
\text { extracurricular }\end{array}$ \\
\hline & & $\begin{array}{l}\text { Module 9. Culture of the Russian people. } \\
\text { Module 10. Culture of the peoples inhabiting } \\
\text { the Republic of Sakha (Yakutia). }\end{array}$ & $\begin{array}{l}\text { activity, public } \\
\text { holidays, and } \\
\text { excursions. }\end{array}$ \\
\hline
\end{tabular}

As presented in the program, classes with the inclusion of ethnic traditions can be varied. It is advisable to use General pedagogical methods, techniques, and tools. In relation to solving the problems of multicultural education, the most relevant ones are: persuasion, and in particular explanation; positive example and demonstration of a positive behavior model; creation of problem situations, success situations, analysis of conflicts, models of behavior styles, decision-making, democratic dialogue; competition. 
Various forms of educational interaction were also tested: press club, youth tolerance club, labor and recreation camps, competitions, local history work, search activities, environmental campaigns, charity movement, Patriotic clubs, museums in the place of residence, etc. The practical orientation of these activities is intended to provide training as a non-traditional form of cultural identification. For example, how an individual can establish interpersonal contacts in a new environment, how he can master the values, norms, and role structures of another culture in relations with a culturally diverse contingent of students.

Education in the context of the indigenous approach depends on how it is selected and the training material is presented and how it affects the student's activity. The main role in this direction is played by the teacher. At the same time, the teacher must comprehend the content of cross-cultural and multicultural education, understand that a variety of behavioral and thinking styles is a universal wealth, and in each social structure, culture, there are certain life-supporting elements that, if they are valued and comprehended by a person, give him a richer and more complete understanding of social relations and virtue. The training material should cover cultural differences in the context of the indigenous approach. Therefore, the teacher must always be ready for a dialogue in a strictly systematized and friendly form.

The program reveals the effectiveness of multicultural education, initial stage of which involves into the element of native culture and language. The middle and high levels bring to the all-Russian and world cultural space basing on the indigenous approach. Thus, multicultural education is the result of the interaction of the ethnos culture, Russian culture and multinational culture of Russia. According to the conceptual provision on the traditional ethnocultural upbringing and education of the children of indigenous peoples of the North, the education of the Russian citizen is conducted basing on the principle of the transition from native sources to the all-Russian civic identity. The traditional pedagogical thought of the indigenous peoples of the North, which is formed through nature-friendly and culture-like upbringing, life and labor, and ethnic upbringing of the bearers of native culture, way of living and language enrich the ethnopedagogical theory and practice, which is based on an indigenous approach.

\section{Discussion}

Volkov, the founder of the Russian ethnopedagogical science and an academician of the Russian Academy of Education (RAE), emphasized special effectiveness of public education: “...in people's traditions, despite the primitive straightforwardness and primitive passivity at first glance, the factors of upbringing appear quite clearly such as nature, game, 
word (thought), labor (action, deed, activity), tradition, everyday life, art, religion, communication, and example. Certainly, the unifying principle is native word..." (Volkov, 2002). Therefore, comprehension of the originality of the inner world of any nation should be based on deep penetration into the features of the traditional way of living and the ethnic system of education. In our opinion, the essence of the indigenous approach is ethnopedagogization of school education for children of indigenous peoples of the North (Neustroev et al., 2017).

The authors provide the main character of the film "The North Wind is Warm" as a typical example. The movie was the winner of a media grant from the Russian Geographical Society. The main character Alexander Kolesov, a reindeer herdsman from EvenoBytantaysky ulus of Yakutia, is a man with his own life philosophy. There is almost a deserted taiga, mountains and tundra for hundreds of kilometers around his house. However, he is not a hermit. He is open to people. There are often guests in his forest house. He learned to love the freedom and nature of the Earth. He appreciates the world where he lives in: everything here has a soul that needs to be respected if you want nature to not reject you. Every day he works: grazes deer, nomadizes, and hunts. He considers all this a pleasure. In general, he has his own philosophical understanding: "happiness is a state of mind", "Even is primarily a child of nature, a nomad", "everything will be fine if you tune into the beat of nature" (Golovkov, 2018). In terms of the traditional ethnic education of the children of the indigenous peoples of the North, the authors of the present research emphasize the necessity to develop a state of mind that "ability to live in native environment is happiness". However, there is also a serious contradiction when most people, living in the North, often complain about their difficult fate.

During active national revival of the indigenous peoples of the North and the expansion of a new form of farming, i.e., ancestral communes, the nomadic schools were also functioning as a mobile form of the school network in the conditions of a nomadic living in taiga, tundra and highlands (Fomenko, 2019). There was an opportunity for traditional family education, the development of the personality of children as carriers of the native language and ethnic culture. The effectiveness and performance of the educational process were ensured by the active labor participation of children in the economic activity of the family. The natural and cultural conformity, as the principles of traditional public education and modern ethnopedagogical theory and practice, have revived.

The composition of Dima Nikitin, a student of the nomadic school "Nerget" of Municipal Budgetary General Education Institution (BGEI) "Sebyan-Kuel national Even 
school named after P. A. Lamutsky" is a vivid example of the development of the children's ethnic identity:

I love my native land. I love its beautiful mountains, rivers and flowers. Every summer I go to my favorite herd with my family. I help brothers graze deer. Nature is my element; I am a child of nature. I have been attracted to it since childhood. I am proud that my ancestral childhood has been preserved. My grandfather is a famous reindeer herder. He is an example for the younger generation. I also want to be like him. From my childhood, my grandfather has told me about the hard work of reindeer herders. I have understood that their work is really difficult in the harsh conditions of the North. However, they work to preserve the traditional work of reindeer herders. We, the students of a nomadic school, must continue the original occupation of our ancestors, which we consider the realization of our happy future.

There is a result of the revival of progressive tradition of public education of the indigenous peoples of the North. It should be emphasized that the family for the peoples of the North is of high importance, which is historically based, since they wandered in small groups of the clan community and were usually isolated from large settlements.

Careful, caring relations between all family members contributed to the upbringing of a healthy child, both mentally and physiologically (Shadrina, 2012). Children grew up obedient and respectful to old people, hardworking and independent. At present, the indigenous peoples of the North are overcoming prevailing stereotypes of the boarding schools implementation in the Soviet period. Children were torn from their parents and from the native element of traditional living for years.

According to the requirements of the new generation of FSES, the qualitative education and upbringing of a Russian citizen should be based on ethnocultural education and training of the children of the North. From these positions, what we should do with a graduate, who has been raising at school for 11 years in isolation from real life, i.e., without a deer, tundra and taiga. What can we offer him at the end of high school?

Real reindeer herders, the parents of these students, are firmly convinced that the deer in the North is still irreplaceable. Of course, they would like to see their children as the successors of their traditional way of life. In fact, the indigenous children of the North have peculiar thinking, mental and physical condition, and behavior, which are adequate to the living conditions in the native environment. 
Teaching staff understand that in new economic conditions in the places of compact residence of indigenous peoples of the North, it is necessary to introduce practical reindeer husbandry and crafts as the basis for the traditional upbringing of the children as the bearers of native language, culture and way of living. Under such conditions of schooling, the foundations of ethnic self-awareness, knowledge, labor skills and competences are developed from early childhood (Pankin, 2004). Before choosing a life journey, a school graduate realizes that he can already say "I know this," "I can do this".

New generation appears which is ready to continue the traditional way of living and activity of the indigenous peoples of the North. This forms the basis for the development of labor resources, training and consolidation of the necessary personnel, increase in the population of indigenous people in places of compact residence of the peoples of the North. There is a process of prosperity of the tribal community settlements, the reclamation of vast territories of ancestral habitats according to the programs for the development of the traditional sectors of the Northern economy, i.e., reindeer husbandry, fishing, hunting, and folk crafts, in the context of new economic relations (Neustroev, Savvin, 2009).

The implementation of the state social policy in the sphere of school education in the North is primarily related to the extension of the social function of the rural school as a sociopedagogical complex in the society (Shergina, Neustroev, 2018). This involves the combination of rural resources and finances to create an appropriate additional base of the complex. Thus, it is necessary to buy reindeer, to include the positions of a reindeer herder, a veterinarian, a hunter, and specialists in national ornamental art and folk crafts in the staffing of the school. According to Northern life realities, the basic curriculum of the Russian schools should be revised for reorienting the vector of educational development to a variable solution of the local problems, taking into account the specific life and activity, as well as natural and climatic, national and regional characteristics of the indigenous peoples of the North, Siberia and the Far East (Neustroev, 2009).

Considering the development of school education in the North in the context of an indigenous approach, the authors of the present research relied on the following fundamental provisions:

- The mentality of indigenous peoples of the North is regarded as a philosophical category, i.e. in order to reveal the content of mentality which is relative to the indigenous peoples of the North, it is necessary to study the origin and formation of the mentality of the dynasty, to correlate it with the concept of consciousness, psyche, 
spiritual culture, and the people's way of living, their native landscape, and, finally, to try to look into his future;

- School education in the North is regarded as a factor of the spiritual transformation of the village, national revival, ethnic mentality and identity of indigenous peoples in the places of their traditional compact residence. The government of the Republic is developing a program for the comprehensive development of the village to achieve a high sociocultural standard of living in the North basing on the principle of the transition from native sources to the all-Russian civil identity and world civilization;

- In the context of active industrial development of the Arctic territories of the Republic of Sakha (Yakutia), the indigenous peoples of the North are being involved into new socio-economic relations. Nowadays, the Arctic uluses of the Republic collaborate on a contractual basis with subsurface users that work in their administrative territory, seeking an active participation in all events where local workers and specialists are in demand;

- Pedagogical wisdom of the indigenous peoples of the North lies in the fact that the effectiveness and performance of the educational process was ensured by the children's active labor participation in the family economy. Nature and cultural conformity have been revived as the principles of traditional public education, as well as modern ethnopedagogical theory and practice;

- The researchers and scientists, who are focused on the indigenous peoples studying, come to the conclusion that Northern rural school is based on the development of a single educational space in the school system, family, village, and surrounding society. Socio-pedagogical complex takes into account all available resources, opportunities and needs; ethno-cultural characteristics, interests and desires of children, social orders for the development of the village and the inhabitants themselves. Additionally, the ideas of the ancestors' life philosophy and older generations' experience are being realized;

- Considering the prospects for the development of school education in the North in the context of an indigenous approach, we rely on special legislative regulatory acts, and guiding documents of the Government of the Russian Federation and the Republic of Sakha (Yakutia) on the problems of the development of indigenous peoples of the North. In particular, the implementation of the "Concept for the Renewal and Development of National Schools in the Republic of Sakha (Yakutia)" has contributed to the revival and development of languages and cultures of indigenous peoples of the 
North, as well as the development of new programs "We Are Children of the Land of Olonkho" for schools with an ethnocultural component of education for the northerners basing on the progressive traditions of public education.

Observation of the pupils in the course of the experimental work was carried out continuously, generalizing sections were made at the diagnostic stage and annually at the practical stage of the research. An increase in the quality of value attitudes in younger schoolchildren occurs in most cases in connection with the accumulation of relationship experience by younger schoolchildren, the use of other methods of forming a value attitude in younger schoolchildren. At the same time, the results of the experiment indicate that the proposed system of educational work is the most effective in the formation of value attitudes towards ethnic traditions and beyond the limits of individuality, more precisely, in a multicultural environment. At this point, the authors relied on the views and conceptual ideas of multicultural education of foreign researchers Y. Garcia and K. Grant that the multiculturalism of upbringing is focused on the study of the native language and on the unique socio-cultural experience acquired by the child himself, which does not in all aspects coincide with the culture groups; and on the priority of the individuality of a particular student, bearer of a particular culture (Garcia, 2002; Grant, 2001). Further, the authors consider the methodological foundations and specific views of the indigenous pedagogy of the North in the context of globalization (Vinokurova, 2015) that the value of nature conservation and people's conservation in the global "We" formula is expressed through the definitions of ecosophy and ecological balance. At the same time, according to U.A. Vinokurova, earlier education served the purpose of unification, maintaining social uniformity (for example, the Soviet common man), then in the context of the global knowledge economy and digital society, the goal of education and upbringing is changing. Now this goal is about identifying, maintaining and developing differences, because it is the differences that provide the basis for innovation and creativity. The leading task of the pedagogical meaning of education is the development of social, emotional and cultural intelligence, the creative principle of the individual.

Thus, in the experimental group, a tendency to an increase in indicators at all stages of work was revealed, but the maximum success of such conditions as the "exit" of the educational process outside the school, socially significant activity of younger students is obvious. Such events as "My neighbors", "Our friendly yard", "How many nationalities live in our yard?", Contests "National costume", "Folk songs and dances" were held. Such events bring together not only children, but also adults. Based on the three levels of formation of value attitudes of 
younger schoolchildren that we established, we identified the average indicator of the value attitudes of younger schoolchildren (Table 2).

\section{Table 2}

Average statistical indicators of the value attitude of primary schoolchildren to ethnic traditions at the control stage of the study (in\%)

\begin{tabular}{cccc} 
Group & Low level & Middle level & High level \\
\hline Experimental & $20 \%$ & $53 \%$ & $27 \%$ \\
Control & $34 \%$ & $47 \%$ & $19 \%$
\end{tabular}

To compare the data of the ascertaining and control stages of the experimental study, let us consider Diagram 1.

Ascertaining experiment

\section{Experimental group}

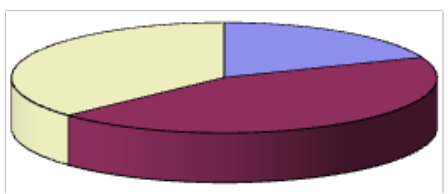

high $-19 \%$

average - $44 \%$

low $-37 \%$

Experimental group

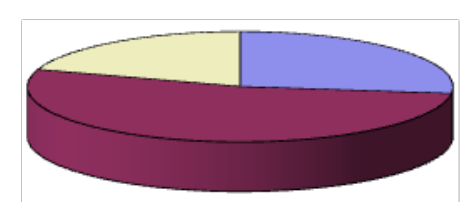

high $-27 \%$

average $-53 \%$

low $-20 \%$

\section{Control group}
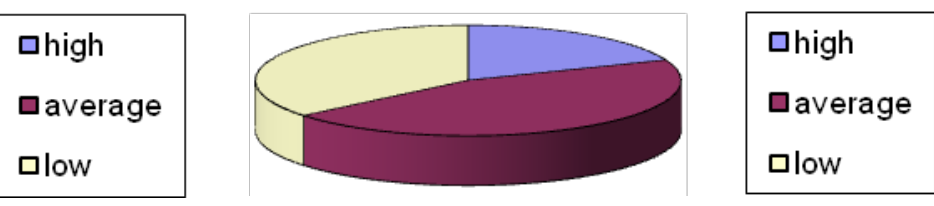

$$
\begin{gathered}
\text { high }-19 \% \\
\text { average }-45 \% \\
\text { low }-36 \%
\end{gathered}
$$

Control experiment

\section{Control group}
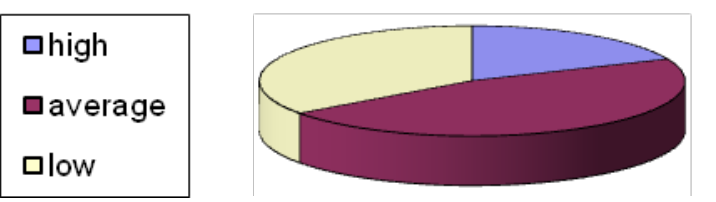

口high

口average

ㅁow

$$
\begin{gathered}
\text { high }-19 \% \\
\text { average }-47 \% \\
\text { low }-34 \%
\end{gathered}
$$

Diagram 1. Indicators of the formation of the value attitude of younger students at the ascertaining and control stages of the study 
These diagrams indicate that at the ascertaining stage of the study, the majority of children in the experimental (44\%) and control (45\%) groups have average values of the value attitude. A high level is characteristic of a small number of younger students: $19 \%$ in the experimental group, $19 \%$ in the control group. A low level is observed in $37 \%$ of children in the experimental group and $36 \%$ in the control group.

The control stage of the study showed the predominance of both the experimental and the control group in children of the average level of value attitude, but qualitatively the picture significantly changed in the experimental group, where the number of children with a high level of value attitude increased by $27 \%$, in the control group the positive dynamics is $19 \%$. The number of children with a low level of value attitudes in the experimental group decreased by $20 \%$, while in the control group - by $34 \%$.

The processing of the results of the ascertaining stage shows that, according to the results of the formative experiment, there is a tendency towards an increase in the number of children with a high level of development of value attitudes towards ethnic traditions beyond indigenousness, in a multicultural environment.

Thus, a comparative analysis of the data obtained at the beginning and at the end of experimental training, proved the effectiveness, expediency and effectiveness of the pedagogical conditions developed by us for the formation of the value attitude of primary schoolchildren to ethnic traditions and the educational program "We are the children of the land of Olonkho".

The implementation of the proposed program and cultural integration contribute to the successful formation of the value attitude of primary schoolchildren to ethnocultural folk traditions. Success is ensured by the fact that cultural folk traditions are presented not only in a folklore and entertainment form, but in the form of a prescribed pedagogical system, where an integrative approach is an effective pedagogical condition.

\section{Conclusion}

Theoretical justification and practical implementation of promising ethno-regional education systems, models of general educational organizations in the North are becoming relevant under current conditions of social development. It is worth highlighting that the tendency to absolutize ethno-regional specificity and to underestimate its specific features is unacceptable in terms of the future development of the socio-pedagogical functions of school education in the North. 


\section{Acknowledgments}

The reported study was funded by RFBR, project number № 19-013-00730 of 24.04.2020.

\section{References}

Afanasyev, V.F. (1979). Ethnopedagogy of Non-Russian Peoples of Siberia and the Far East. Yakutsk: Yakutsk Publishing House.

Baisheva, M., Grigoryeva, A., Neustroeva, A., Borisova, T., Sidorova, E., Iliynova, T. (2017). Spiritual dominance of the Sakha people traditional belief in the personality development of children. Journal of Social Studies Education Research, 8(3), 139148. https://files.eric.ed.gov/fulltext/EJ1162286.pdf

Baklanova, T.I. (2015). Ethnocultural Pedagogy: Problems of Russian Ethnocultural and Ethno-artistic Education: Monograph. Saratov: "Vuzovskoye Obrazovaniye" Publishing House.

Beaulieu, D. (2006). A survey and assessment of culturally based education programs for Native American Student in the United States. Journal of American Indian Education, 45(2), $50-61$. https://citeseerx.ist.psu.edu/viewdoc/download?doi=10.1.1.473.3199\&rep=rep1\&type $=\mathrm{pdf}$

Biermann, S., Townsend-Cross, M. (2008).Indigenous pedagogy as a force for change. The Australian Journal of Indigenous Education, 37S, 146-154. DOI: $10.1375 / \mathrm{S} 132601110000048 \mathrm{X}$

Bishop, R., Glynn, T. (1999). Culture Counts: Changing Power Relations in Education. Dunmore Press. DOI: 10.2307/3099882

Bugaeva, A.P., Buryak, O.V. (2019). Game technologies as a means of preserving the traditional knowledge of the indigenous peoples of the North. Global Scientific Potential, 12(105), 20-25. https://elibrary.ru/item.asp?id=42502582

Chilisa, B. (2012). Indigenous Research Methodologies. London: Sage Publication Ltd. http://cjc-rcc.ucalgary.ca/index.php/cjpe/article/view/30946/pdf

Fomenko, G. (2019). We must build the Arctic from scratch. Yakutia, 26.

Garcia, E. (2002). Student Cultural Diversity: Understanding and Meeting Challenge. Boston.

Golovkov, A. (2012). Happiness is a state of mind! Yakutsk vecherniy.

Grant, K., Gomez, M. (2001). Campus and Classroom: Making Schooling Multicultural. New Jersey,

Harvey, G. (2002). Readings in indigenous religions. London: Continum. 
Ismail, R., Gopalasamy, R.C., Saputra, J., Puteh, N. (2019). Impacts of a colonial policy legacy on indigenous livelihoods in Peninsular Malaysia. Journal of Southwest Jiaotong University, 54(5). DOI: 10.35741/issn.0258-2724.54.5.18

Kawagley, O.A. (1995). A Yupiaq Worldview: A Pathway to Ecology and Spirit. Long Grove: Waveland Press. ISBN-13: 978-1577663843.

Kovach, M. (2009). Indigenous Methodologies: characteristics, conversations and contexts. University of Toronto Press. https://utorontopress.com/us/indigenous-methodologies-4 Kozhurova, A.A. (2015). Formation of Younger Schoolchildren's Value Attitude to Ethnic Traditions in a Multicultural Environment. Monograph. Yakutsk: NEFU Publishing House.

Marfusalova, V.P. (2020). The system of ethnocultural education in the Arctic: monograph. Yakutsk: NEFU Publishing House.

Merlan, F. (2009). Indigeneity: Global and local. Current Anthropology, 50(3). DOI: $10.1086 / 597667$

Mihesuah, D.A. (1998). Natives and Academics: Researching and Writing about American Indians. Lincoln: University of Nebraska Press. DOI: 10.2307/970495

Moreton-Robinson, A.M., Walter, M. (2009). Indigenous methodologies in social research. In: Walter, M. (Ed.). Social research methods: An Australian Perspective. Oxford University Press, South Melbourne, Vic, 1-18. ISBN-13: 978-0195555301, ISBN-10: 0195555309.

Mukhamedzyanova, G.V. (2011). The dialogue of cultures and the partnership of civilizations as a humanitarian component of professional education. Scientific foundations of the development of education in the 21st century. Collection of scientific works. Saint Petersburg: University of the Humanities and Social Sciences.

Neustroev, N., Neustroeva, A., Shergina, T. (2018a). Individualization and Ethnopedagogy at Small Elementary Schools: Components of Vocational Training for University Tutors. Sibirica: Indigenous Methodology in the Study of the Native Peoples of Siberia, 17(3), 92-115. https://www.berghahnjournals.com/view/journals/sibirica/17/3/sib170309.xml Neustroev, N., Neustroeva, A., Sakerdonova, A., Sleptsov, Y., Rufov, B. (2018b). Small school as a sociocultural center in rural settlements of the North-East of Russia: search for the ways to preserve and develop. Revista ESPACIOS, 39(23). https://www.revistaespacios.com/a18v39n23/18392316.html

Neustroev, N., Sleptsov, Y., Neustroeva, A., Shergina T., Kozhurova, A. (2019). Traditional Even Child Rearing in Nomadic Conditions. Journal of Computational and 
Theoretical

Nanoscience,

$16(12)$

$5186-5196$.

https://www.ingentaconnect.com/content/asp/jctn/2019/00000016/00000012/art00046; jsessionid=61p3gco2aeccd. $\mathrm{x}$-ic-live- 01

Neustroev, N.D., Neustroeva, A.N., Sakerdonova, A.S., Shergina, T.A. (2017). Tutoring in the primary, basic ungraded and nomadic school of the North: monograph. Yakutsk: NEFU Publishing House.

Neustroev, N.D., Savvin, A.S. (2009). National traditions of Russian education in the context of Bologna process. Moscow: Academia.

Nikolaeva, A.D. (2013). Innovative processes in education. Textbook. Yakutsk: Publishing house of North-Eastern Federal University.

Nikolaeva, A., Marfusalova, V., Bugaeva, A., Shadrina, S. (2020). Creating ethnocultural space in the process of school education in the Arctic region. Journal of History Culture and Art Research, 9(3), 72-82. DOI: 10.7596/taksad.v9i3.2820

Pankin, A.B. (2006). Development of ethnocultural personality: Learning guide. Moscow: Publisher of Moscow Psychology and Sociology Institute.

Semenova, A.D. (2004). Pedagogical heritage and professional competence of a modern teacher. Yakutsk: YaGU Publishing House.

Sergeeva, N., Shevchenko, O., Klimenko, T., Shcherbakova, L., Tikhonovskova, M. (2018). Ethnocultural education as a factor of the spiritual security of the Russian polyethnic society. Journal of History Culture and Art Research, 7(5), 157-167. DOI: 10.7596/taksad.v7i5.1908

Shadrina, S.N. (2012). Traditions of children's moral education in foreign studies. Teacher of $\begin{array}{llll}\text { the } & X X I & \text { century, } & 1(4), 173 .\end{array}$ https://drive.google.com/file/d/0Bww8v66PaPfWUXNGU114Um1Jc0E/view

Shergina, T.A., Neustroev, N.D. (2018). Modernization of the Educational Process of a Small Rural School in the North: Monograph. Yakutsk: NEFU Publishing House.

Smith, G.H. (2005). The problematic of 'Indigenous theorizing': a critical reflection. The AERA Annual Conference, Montreal.

Strathern, M. (2004). Partial Connections, Updated Edition. Walnut Creek: AltaMira Press. ISBN-13: 978-0759107601.

Trouillot, M.-R. (2003). Global Transformations. Anthropology and the Modern World. New York: Palgrave Macmillan. https://www.palgrave.com/gp/book/9780312295202 Vinokurova, U.A. (2017). Indigenous Methodology in Ethnopedagogy. Ethnopedagogy of Love and National Salvation: A Collective Monograph. Ministry of 
Education and Science of the Republic of Sakha (Yakutia). Yakutsk: Yakutia Media Holding.

Vinokurova, U.A., Semenova, S.S. (2015). Ethno-cultural education far Eastern Federal District of the Russian Federation. Yakutsk: Yakutia Media Holding.

Vinokurova, U.A., Yakovets, Yu.V. (2016). Arctic circumpolar civilization: Educational edition. Novosibirsk: Nauka.

Volkov, G.N. (2002). “The Love Pedagogics”. The Selected Ethnopedagogical Works: in 2 vol. Moscow: Magister-Press. 